\title{
Law Enforcement against the Implementation of the Provisions Payment of Workers' Wages is Reviewed from Aspects of Employment Criminal Law
}

\author{
Siti Nurhayati ${ }^{1}$, Sumarno ${ }^{2}$ \\ ${ }^{1,2}$ Law Study Program, Social Science Faculty, Universitas Pembangunan Panca Budi, Medan, Indonesia, 20122
}

Corresponding Author: Siti Nurhayati

\begin{abstract}
Wage problems are the most commonly disputed issues between workers and employers, which can result in disharmony in employment relationships. For the workers / workers see wages as a source of income to meet the needs of life and family, while on the part of employers see wages as one of the burdens that must be borne because it is part of the cost of production. Employers who pay wages lower than the minimum wage are part of the criminal law of the employment field. The position of employment law in the field of criminal law needs to be applied so that criminal matters related to employment can be enforced on this civilized and civilized earth. Doctrinal research type, normative juridical. The results obtained from this study that wage payments below the District Sector Minimum Wage (UMSK) are not only sanctioned by the company but also subject to criminal sanctions in accordance with Article $88 \mathrm{E}$ paragraph (2) juncto Article 185 of Law No. 11 of 2020 on Copyright Work. The reason for wage payment under UMSK is due to the situation and condition of the company that is not financially able to make a joint agreement between workers / workers and the company can't be legally allowed The Company has not filed a suspension of wage payments under UMSK to the Department of Manpower and Transmigration, so the Company's actions are contrary to the legislation and null and void and the Court can impose a prison sentence of 2 (two) years in prison and a fine of Rp. 200,000,000.00 (two hundred million rupiah).
\end{abstract}

Keywords: Law Enforcement, Wage Payment, Criminal Employment

\section{INTRODUCTION}

Wage problems are the most commonly disputed issues between workers and employers, which can result in disharmony in employment relationships. For the workers / workers see wages as a source of income to meet the needs of life and family, while on the part of employers see wages as one of the burdens that must be borne because it is part of the cost of production.

The success of a company depends on the workers, the relationship between the company and these workers need each other, on the one hand workers need a company for where they work, on the other hand the company also needs workers as a resource to deliver the company to achieve its goals. Realizing the importance of workers for companies, governments and communities, it is necessary to think so that workers can maintain their safety in carrying out their work. Similarly, it is necessary to strive for the calmness and health of the worker so that what he faces in the job can be considered as much as possible, so that vigilance in carrying out the work is still guaranteed. These thoughts are worker protection programs that in daily practice are useful to maintain productivity and stability of the company.

The problem that often occurs in the practice in the field that many employers pay the minimum wage of workers lower than the Minimum Wage, whereas in Article 90 paragraph (1) law No. 13 of 2003 on 
Employment hereinafter referred to as UUK, the scattered thing is also stipulated in Article $88 \mathrm{E}$ of the Copyright Act, hereinafter referred to as UUCK, states that employers are prohibited from paying wages lower than the minimum wage as referred to in Article 89. Cases that have occurred such as an entrepreneur paying wages lower than the minimum wage, an entrepreneur from Surabaya was sentenced to one year in prison and a fine of Rp.100,000,000 (one hundred million rupiah). The reason, the employer was proven to pay the wages of 53 workers under the provisions of regional minimum wages and also in the news of the Liputan6.com (economic news)

Employers who pay wages lower than the minimum wage is part of criminal law, as one of the efforts for the welfare of society in general, then this law enforcement policy is included in social policy, namely all rational efforts to achieve the welfare of the community. As an issue that includes policy issues, the use of criminal law is not actually a necessity. There is no absoluteness in the field of policy, because it is essentially in the matter of policy assessment and selection of various alternatives. Thus, the problem of controlling or tackling crime using criminal law, is not only a social problem as stated by Packer above, but also a policy issue (Teguh Prasetyo, 2010).

The principle of legality in Article 1 paragraph 1 states that no act can be punished, except based on the strength of pre-existing laws and regulations. One of the legal issues that is also a legal issue today is the policy of criminal law in the field of employment crimes. (Andi Hamzah, 2007) Imam Soepomo as mentioned in his book Abdul R. Budiono defines that employment law is a law that regulates the relationship between employers, workers and other parties with the main purpose of providing protection to workers. (Abdul $\mathrm{R}$. Budiono, 2015) This definition is conveyed by reason:
1. Relationships governed by employment law are primarily the relationship between employers and workers,

2. At the next stage, the relationship governed by employment law is the relationship between the employer and the other parties, or the relationship between the worker and the other parties.

3. The main purpose of employment law is to provide protection to workers. (Abdul R. Budiono, 2015)

While Zaeni Asyhadie uses the term work law as a series of rules that regulate all events related to the work of a person in others by receiving wages. (Zaini Asyhadi, 2017) One particular feature of employment law is that this branch is a functional field of law that combines all other legal branches with regard to the specific theme of working under an employer (subordinated labour). The basic nature of labor law is not easy to classify following the traditional division of branching of the legal system. (Budi Santoso, 2012)

Many people still see that employment law is limited to the relationship of employers and workers or limited to civil matters. Whereas looking at the definition that has been explained by Imam Soepomo and the special characteristics that exist in employment law can be said that employment law is a public law, which includes administrative law and also criminal law. Where the government can enter and interfere in its implementation. By its nature, employment law has a position in the Indonesian national legal system in the areas of administrative law, civil law, and criminal law.

Based on the description above, it can be explained that the position of employment law in the Indonesian national legal system can theoretically be separated into 3 areas, namely the field of administration, civil sector, and criminal field. But in practice it must be run simultaneously because it relates to each other. Legal relationships conducted by workers / workers with employers are 
included in the field of civil law. But during the process of making, implementing, and ending the relationship is supervised by the government in order to carry out its 3 functions. If during these processes there are violations (not in accordance with applicable regulations), then criminal sanctions can be applied. With regard to the position of employment law in the field of criminal law, criminal law policy needs to be applied so that criminal matters related to employment can be enforced on this civilized and civilized earth.

Based on the provisions of Article 176 paragraph (1) of the Labor Law, it is mandated that employment supervision is carried out by employees of the employment supervisor who have competence and independent to ensure the implementation of employment legislation. Therefore, if there is a criminal act of employment, then all that must be done is to report to the Employee Supervisory of employment at an agency whose scope of duties and responsibilities in the field of employment in the central government, provincial government and district / city government. An interesting thing to review in relation to criminal law policy against criminal acts in the field of employment is the thickness of civil problems and state administrative problems in labor law so rarely found criminal cases related to employment issues. Although uuk there regulates in its articles concerning labor crimes, but both workers and other organs related to employment relationships do not understand the meaning of labor crimes.

\section{LITERATURE REVIEW Law Enforcement}

Law enforcement is an effort to bring ideas of justice, legal certainty and social benefits into reality. So law enforcement is essentially the process of embodiment of ideas. Law enforcement is the process of establishing or functioning legal norms in real terms as a guideline for perpetrators in traffic or legal relationships in public and state life. (Dellyana Shant, 2008)

Concrete enforcement is the enactment of positive laws in practice as it should be adhered to. Therefore, providing justice in a case means deciding the law in concreto in maintaining and guaranteeing the adherence of material law by using procedural means established by formal law. According to Satjipto Raharjo law enforcement is essentially the enforcement of ideas or concepts of justice, truth, social benefits, and so on. So law enforcement is an effort to realize these ideas and concepts into reality. In fact, law enforcement embodies the values or methods that contain justice and truth, law enforcement is not only the duty of law enforcement officials who are already known conventionally, but become the duty of everyone.

\section{Implementation of Worker Wage Payments}

Wages are the rights of workers or employees received and expressed in the form of money in return from employers or employers to workers that are determined and paid according to an employment agreement, agreement or legislation, including benefits for workers and their families for a job and or service that has been or will be done. (Statutory Regulation, 2006) The definition of wages according to Islam is the provision of a service (benefit) that is expected to be realized, such as the provision of wages to employees who have worked to advance their company, so wages or also called is a form of wage for a success (achievement) of a job. (Imam Soepomo, 2018) Wages are a reward from companies that have received employment from the workforce and are generally the goal of the employee or to do the work. If there is no wage, in general there is also no working relationship, for example the work done in mutual relations.

In general, wages are incomes that play a role in the life of employees to meet the needs of their families, so it is appropriate that an employee gets: 
a. Earn a sufficient amount of income that is considered in order to guarantee the basic needs of his life and his family.

b. Feel satisfaction regarding the conformity with the income of others who do similar work in their company or in other businesses in the community.

In establishing a good working relationship, on the issue of wages the employee should also think about the situation in his company, if the company is not able to pay the same wages as in other companies then as employees should not demand the same wage payments as in other companies, but at this time there are still many other employers who still rely on labor with little wages that are not in accordance with the employee's work.

About the types of wages, there are several types that are stated as follows:

a. Nominal wage referred to as nominal wage is a sum of money paid to employees who are entitled in cash in return for the deployment of services or services in accordance with the provisions contained in the employment agreement in the field of industry or company or in an organization of work, wherein there is no additional wages or other benefits given to him. This nominal wage is often also called money woges in relation to its existence which is indeed in the form of money in its entirety.

b. Real wages (real woges) are real money wages that a person who is entitled to actually receive. This real wage is determined by the purchasing power of the wage that will depend a lot from:

1. The amount or small amount of money received.

2. The size or small cost of living required. Sometimes the wages are received in the form of money and facilities or in natura, then the real wages received are the amount of wages and the value of rupiah from the facility.

c. The living wage, in this case the wages received by an employee is relatively sufficient to finance the needs of a wider life, not only the basic needs that can be met but also some of the social needs of the family, such as life insurance contributions, education and some others.

d. Minimum wage

As explained that the income generated by employees in a company is very important role. In this case, the minimum wage should be able to meet the living needs of employees and their families, although in a simple sense, the cost of living needs to be considered in determining wages.

\section{Employment Criminal Law}

What is meant by a criminal act (delik) or according to Prof. Moeljatno, S.H., criminal acts are prohibited by a rule of law, prohibitions which are accompanied by threats (sanctions) in the form of certain crimes, for anyone who violates the provision, while according to Prof. Wirjono Projodikoro, S.H. which is meant by a criminal act means an act whose perpetrator can be penalized.

As for the crime of employment, is a violation of the rules of labor law whose perpetrators can be penalized. Criminal acts in the field of employment consists of 2 (two) types, namely, criminal acts and criminal violations. in:

Criminal acts, namely as stipulated

1. Law of the Republic of Indonesia Number 13 of 2003 concerning Employment, namely:

a. Article 183 paragraph (1) Anyone who violates the provisions as referred to in Article 74 shall be subject to a maximum prison sentence of 2 (two) years and a maximum of 5 (five) years and/or a fine of at least Rp.200,000,000.00 (two hundred million rupiah) and a maximum of Rp.500,000,000.00 (five hundred million rupiahs).

b. Article 184 paragraph (1) Anyone who violates the provisions as referred to in Article 167 paragraph (5), shall be 
subject to a prison sentence of at least 1 (one) year and a maximum of 5 (five) years and/or a fine of at least Rp.100,000,000.00 (one hundred million rupiah) and a maximum of Rp.500,000,000.00 (five hundred million rupiahs).

c. Article 185 paragraph (1) Whoever violates the provisions as referred to in Article 42 paragraph (1) and paragraph (2), Article 68, Article 69 paragraph (2), Article 80, Article 82, Article 90 paragraph (1), Article 143 and Article 160 paragraph (4) and paragraph (7), shall be subject to imprisonment for a maximum of 1 (one) year and a maximum of 4 (1 years and/or fines of at least Rp.100,000,000.00 (one hundred million rupiah) and a maximum of Rp.400,000,000.00 (four hundred million rupiahs).

2. Law of the Republic of Indonesia Number 21 of 2000 concerning Trade Unions/Trade Unions, namely:

Article 43 paragraph (1) Whoever obstructs or coerces workers as referred to in Article 28, shall be subject to a maximum prison sentence of 1 (one) year and a maximum of 5 (five) years and/or a fine of at least Rp.100,000,000.00 (one hundred million rupiah) and a maximum of Rp.500,000,000.00 (five hundred million rupiah).

While the criminal offences, among others as stipulated in: Law of the Republic of Indonesia Number 13 Year 2003 on Employment, namely:

a. Article 186 paragraph (1) Whoever violates the provisions as referred to in Article 35 paragraph (2) and paragraph (3), Article 93 paragraph (2), Article 137 and Article 338 paragraph (1), shall be penalized with imprisonment for a minimum of 1 (one) year and at most 4 (four) years and/or a fine of at least Rp.100,000,000.00 (one hundred million rupiah) and a maximum of Rp.400,000,000.00 (four hundred million rupiahs). b. Article 187 paragraph (1) Whoever violates the provisions as referred to article 37 paragraph (2), Article 44 paragraph (1), Article 45 paragraph (1), Article 67 paragraph (1), Article 71 paragraph (2), Article 76, Article 78 paragraph (2), Article 79 paragraph (1) and paragraph (2), Article 85 paragraph (3), and Article 144, shall be subject to a maximum prison sentence of 1 (one) month and a maximum of 12 (twelve) months and/or a fine of at least Rp.10,000,000.00 (ten million rupiah) and a maximum of $\mathrm{Rp} \mathrm{100,000,000.00}$ (one hundred hundred million rupiah).

c. Article 188 paragraph (1) Whoever violates the provisions as referred to in Article 14 paragraph (2), Article 38 paragraph (2), Article 63 paragraph (1), Article 78 paragraph (1), Article 108 paragraph (1), Article 111 paragraph (3), Article 114, and Article 148., shall be subject to a penalty of at least Rp.10,000,000.00 (ten million rupiah) and a maximum of Rp.100,000,000.00 (one hundred hundred million rupiah).

Based on the provisions of Article 176 paragraph (1) of the Law of the Republic of Indonesia Number 13 of 2003 concerning Manpower, it is mandated that employment supervision is carried out by competent and independent employment supervisory employees to ensure the implementation of employment laws and regulations. Therefore, if there is a criminal act of employment, then all that must be done is to report to the Employee supervisory of employment on the scope of duties and responsibilities in the field of employment in the central government, provincial government and district / city government.

The process of handling cases in the field of employment in general, can be described as follows:

1. The whistleblower reports the alleged labor crimes to the Employment Supervisory Officer at the local Labor Office. 
2. On the basis of the report of the Reporter, the Supervisory Officer, conducts a series of surveillance activities / examination of alleged labor crimes.

3. After the examination was found to be no criminal employment, then the Supervisory Officer gave a Memorandum of Coaching.

4. If after being given a Memorandum of Construction was not conducted, then the Supervisory Officer submits his case to the Civil Servant Investigator for investigation.

5. Civil Servant Investigators send a Notice of commencement of investigation to the Police Investigator.

6. After the Civil Servant Investigator has finished the investigation, then made the Case File

7. After the completion of the filing of the Civil Servant Investigators delegated to the Public Prosecutor through the Police Investigators.

After the Public Prosecutor receives the Case File and declares it complete, the Public Prosecutor submits to the District Court for trial.

\section{METHODOLOGY}

The type of research used is doctrinal research. Doctrinal research is a study that produces systematic explanations of legal norms that govern a particular legal category, analyzes relationships between legal norms, explains difficult areas, and is expected to also provide predictions about the development of legal norms in the future. This type of research will be used to explain the problem formulation in this thesis. The approach used in this legal research is the Statute approach and the conceptual approach.

The legal approach is done by studying all laws and regulations related to law enforcement against the implementation of wage payment provisions of workers reviewed from the aspect of employment criminal law. The legal approach in normative legal research has practical and academic uses. This approach is used to examine more deeply on the issue so that later get the results of an argument to solve the case about law enforcement against the implementation of wage payments from the criminal aspect of employment) and conceptual approach.

Conceptual approach according to Peter Mahmud, departing from the views and doctrines that developed in the science of law. Still according to Prof. Peter, conceptual approach is done while researchers do not move from the existing rule of law. It was done because it has not been or there is no rule of law for the problems faced. (Peter Mahmud M, 2005)

\section{RESULTS AND DISCUSSION \\ Criminal Law Policy against Criminal Acts in the Field of Employment \\ Criminal Acts in the Field of Manpower}

The basic policy in Employment Law is to protect the weak, in this case workers/ workers, from the arbitrariness of employers / employers that can arise in the employment relationship with the aim of providing legal protection and realizing social justice. The emergence of employment law due to the inequality of bargaining positions contained in the employment relationship (between workers / workers and employers / employers), with the reason can also be seen the main purpose of employment law is to eliminate the inequality of relations between the two. To achieve the purpose of law in general, namely justice, usefulness, and legal certainty, it is necessary to process the formation and implementation of the law in order to fit the purpose, therefore it is necessary to legal politics.

In this case the politics of law as a basic policy is also intended as a means in order to realize the development of national law. However, according to Sunaryati Hartono, the law is not a goal but only a bridge that will lead to the idea that is aspired, the idea that is aspired to is nothing but the purpose of the law itself, namely justice, usefulness, and legal certainty. In an 
effort to realize the development of national law, the politics of law determines the law that should apply to regulate various things of life with public and state life, which is often termed by legal policy. The government (state) should be able to position itself as a wise regulator through the advice of the establishment and implementation of Employment Law, because labor law will be a means to carry out government policies in the field of employment itself.

The use of legal efforts, including criminal law, as an effort to address social issues is included in the field of law enforcement policy. In addition, because the goal is to achieve the welfare of society in general, the law enforcement policy is also included in the field of social policy, namely all rational efforts to achieve the welfare of the community. Marc Ancel once said, that "modern criminal science" consists of three components "Criminology", "Criminal Law" and "Penal Policy". It was suggested by him, that "Penal Policy" is a science as well as an art that ultimately has a practical purpose to enable positive legal regulations to be formulated better and to provide guidance not only to lawmakers, but also to the courts that apply the law and also to the organizers or executors of court decisions.

The use of penal facilities (criminal law) in criminal policy has two central problems, namely what acts are actually criminal acts and what sanctions should be used or imposed on the offender. The first central problem is often referred to as criminalization. According to Soerjono Soekanto, criminalization is an act or determination of the ruler regarding certain acts of conduct that by the community or groups of people are considered as acts that can be criminalized or make an act into a criminal act and therefore can be criminalized by the government by working on its behalf. Criminalization can also be interpreted as the process of determining an act of a person as an act that can be criminalized or a process of elevating an act that was not originally a criminal act into an act that can be criminalized. (Soejono Soekanto, 2008)

Sudarto argues that in the face of the first central problem of criminalization, should pay attention to some things that are essentially about the use of criminal law should pay attention to the purpose of national development, namely realizing a fair and prosperous society that is evenly material spiritual based on Pancasila, regarding acts that are attempted to be prevented or addressed by criminal law must be an undesirable act that is an act that brings harm (material and or spiritual) to the citizens, concerning the use of criminal law must pay attention to the principle of cost and results, and regarding the use of criminal law must also pay attention to the capacity or capability of the work force of law enforcement agencies so that there should not be overbelasting. There are general criteria in determining an act to be a criminal act because not all actions can be criminalized, the general criteria referred to are as follows: (Soejono Soekanto, 2008)

a. Whether it is disliked or hated by the community because it is detrimental, or can harm, bring sacrifices or can bring sacrifices.

b. Whether the cost of criminalizing is balanced with the results to be achieved, meaning the cost of law enforcement and supervision, as well as the burden carried by victims, perpetrators and perpetrators of the crime itself must be balanced with the situation of legal order to be achieved.

c. Whether to increase the burden of law enforcement officers who are not balanced or manifestly can not be carried by the capabilities they have.

d. Whether these actions hinder or hinder the ideals of the nation, so that it is a danger to the whole community.

Related to the explanation of the criminalization, it can be concluded that against every act of employers to workers / workers who cause losses both materially and spiritually, acts that are not desired by the community (in this case especially the 
workers / workers), can be criminalized into a criminal act. Related to the criminalization of the actions of employers who cause such losses, in order to uphold the justice and welfare of workers / workers, protect the rights and obligations of workers / workers from the arbitrariness of employers, and cause a deterrent effect to employers formed a law that specifically regulates the conduct of the work that is considered to harm workers / workers as a criminal act that is threatened with a criminal sanction, either in the form of administrative crimes, fines, criminal confinement, and prison.

In response, the government issued several laws and regulations governing various matters in the field of employment for the creation of welfare of workers or workers, including regulating criminal provisions against criminal acts contained in the field of employment. This is useful to protect the position of workers who are still very weak in the world of work, so that countries have an obligation to protect their rights and obligations from the arbitrariness of employers or their employers. Along with the increasing pace of development and industrialization process, more and more laws and regulations are made to protect workers or workers in several aspects and by including criminal provisions in it. This means that a criminal politics using a criminal law policy is an effort or measures made deliberately and consciously, choosing and establishing criminal law as advice to tackle crime.

In order to achieve the welfare of the community, especially in this case are workers / workers, and to prevent the occurrence of criminal acts against workers / workers, the government took a policy to use the means of "penal" (criminal law) namely by issuing legislation on employment that is governing and protecting the rights and obligations of workers / workers by including criminal provisions into it, both in the form of administrative crimes, fines, criminal confinement, and prison crimes, so that it is expected that it can cause a deterrent effect and become one of the efforts to combat criminal acts in the field of employment.

As it is known that the state of Indonesia is a country of law (Djoko Heroe. S, 2006), and one characteristic of the state law is the recognition of human rights. As a legal state based on Pancasila must reflect the existence of the soul of the nation and animate, as well as underpin the prevailing laws in order to realize the general welfare and discipline, which contains juridical consequences that every citizen and state official, where all his actions must be based on the law.

The term state of law (rechtsstaat) was used by Rudolf von Gneist (German1816-1895) of the XIX century in his work: "das Englische Verwaltungerechte" for the British government. (Fadjar A. Mukthi, 2014) In encyclopedia Indonesia, the term state of law is formulated as a country that aims to organize the order of law (discipline based on the law) and so that everything goes according to law. (Azhary, 2015)

The term state of law has the equivalent of the word "The Rule of Law". This is stated by Sunaryati Hartono, namely: "Therefore, in order to create a legal state that brings justice to all the people concerned, the recognition of "The Rule of Law" must be interpreted materially" (Azhary, 2015)

According to Schelterma itself elements of rechtsstaat, namely: First, legal certainty (including the principle of legality, the law governing law enforcement actions, the law does not apply retroactively, human rights are guaranteed by law, control is free from the influence of other powers). Second, equality (the authorized action is regulated by law in a material sense, as well as the separation of powers). Third, democracy (the right to vote and be elected, the regulation of the authorized body is set by parliament, as well as parliament overseeing government actions). Fourth, government for the people (human rights are guaranteed by the Constitution, and 
government effectively and efficiently). (TH. Hutagalung, 1995)

Mukthie Fadjar stated that the absolute requirement and characteristic of the state of law, namely the principle of recognition and protection of human rights, the principle of legality. Fadjar A. Mukthi, 2014) From the above views can be understood that the existence of Indonesia as a state of law is identified in the Constitution.'45, which is explicitly listed and spread across various articles, namely: Article 1 paragraph (2) and paragraph (3), Article 24 paragraph (1), Article 27 paragraph (1) and paragraph (2), Article 28, Article 28 A, Article 28B, Article 28 D paragraph (1) and paragraph (2), Article 28 F, Article $28 \mathrm{G}$, Article $28 \mathrm{H}$ paragraph (1), (2), (3) and Article 28 I paragraph (1), (2), (5) and Article $28 \mathrm{~J}$ of the 1945 Constitution. The articles, in general, are manifestations of a state law, as well as specifically as the basis of employment law, especially in the provisions of Article 27 paragraph (2), Article 28D paragraph (1) and paragraph (2), Article $28 \mathrm{H}$ paragraph (3), and Article 28I (2) of the Constitution'45. Thus it can be stated that employment law as a normative legal norm, and is a legal basis in industrial relations (employment), as intended in the provisions of the 1945 Constitution, subsequently the issuance of Law No. 13 of 2003 on Employment, based on the provisions of Article 5 (1), juncto Article 20 paragraph (2), jo. Article 27 paragraph (2), Juncto Article 28, Juncto Article 33 paragraph (1) of the 1945 Constitution, which characterizes legal certainty, as well as justice as the state cirri law. The principle of legal certainty as the state cirri of law is also stipulated in the criminal law Article 1 (1) KHUP, reads: "No act can be criminalized, except for the strength of criminal rules in the legislation that existed before the act was done". The principle of law (legality) in a narrow sense is known as adagium: "Nullum Delictum, Nulla Poena, Sine Praevia Lege Poenale", while in the broad meaning (covering criminal procedural law), the Prosecutor is obliged to prosecute all persons deemed to have reasonably reasoned that he had broken the law".

\section{Normative Regulatory Objectives regarding Employment Relations}

What about the employment law that has two areas of law, namely public and private law. In this case, as described at a glance above, that employment law has a protective nature, coercion and sanctions, while in the private realm there is a contractual legal relationship in order to conduct production activities based on the principle of balance of interests. As with other laws, employment law has a function and purpose to maintain public order, especially the relationship between employers and workers in the production process of goods and services, which contains and reflects the value of legal certainty, usefulness value (benefit), and the value of justice. Here these three values as pillars that underlie the establishment of labor law, and at the same time as the purpose of employment law. (Majda ElMuhtoj, 2015)

As it is known that one element of the state law there is human rights as a basic right, which has naturally been attached to the human being since he was born and can not be revoked in such a way, if deprived of that right then his presence in the social realm will lose his existence as a human being. This is according to Wolhoff's statement, that a number of rights that seem to be rooted in the habits of every human being precisely because of his humanity that can not be revoked by anyone because if revoked is lost also humanity". ( Majda ElMuhtoj, 2015) The inclusion of human rights formulation in the 1945 Constitution, as a guarantee of respect and protection of human dignity and dignity, in addition as one of the conditions for the fulfillment of elements of the state law. Similarly, the law as a means of achieving order, welfare, and justice in regulating the rights of citizens must be able to demonstrate guaranteed protection of the right to decent 
employment, free choice of employment, right to employment conditions, right to a fair wage and the terms of proposional employment agreements. Other rights, establishing unions and not being allowed to impedes workers as members. (EW. Pujirahayu, 2011)

In support of the principle of human rights, John Rawls, through his work A Theory of Justice, states that: First, the general principles of justice underlie a variety of moral decisions; Second, the mind of justice lies in the social structure (society), such as: social institutions, politics, law, economics. Community structure, including the constitution, personal ownership of production facilities / infrastructure, competitive markets that require the cooperation of all parties; Third, the principle of equal freedom for all people (freedom in the fight for the rights and / or interests of the law), in which contained aspects of differences and similarities, namely the principle of social and economic differences must be regulated in order to provide the greatest benefits for the most disadvantaged such as welfare, income and authority, while the principle of equality, namely justice over opportunity. This means that everyone has the same rights and opportunities to gain freedom in accordance with the principles of human rights. (Majda El-Muhtoj, 2015) From the description above, it can be explained that the inclusion of human rights formulation in the 1945 Constitution shows the existence of legal guarantees, and democracy as an option in the system of government and is a manifitasi of the implementation of human rights.

\section{Liability for Wage Payment Under the District/City Minimum Wage}

Wages in Article 1 of Government Regulation No. 36 of 2021 concerning Wages are: "The rights of workers or workers received and declared in the form of money in return from employers or employers to workers / workers are determined and paid according to an employment agreement, agreement, or legislation, including benefits for workers or workers and their families, for a job and / or service that has been or will be done".

In wages there are several types of wages, namely the following:

a. Wages based on Employment Agreement Status

1) Fixed wages are wages paid by employers to workers or permanent workers or commonly called salaries. The fixed salary is not affected by anything, either by overtime or other factors.

2) Non-fixed wages are wages paid by employers to workers or workers on an irregular basis. The non-fixed wages are influenced by the small amounts of wages for overtime work or other factors performed by workers or workers. The more overtime work or other factors are done, the greater the wages received by the worker or worker concerned.

3) Daily wages are wages paid by employers to workers or workers on a daily basis or based on attendance level. This wage applies to freelance day laborers.

4) Wholesale wages are wages paid by employers to workers or workers in bulk or based on the volume of work units of work.

b. According to the time of payment

1) Monthly wages are wages paid by employers to workers or workers on a monthly basis. Usually at the end of the month or the beginning of the following month. So wages are paid once a month.

2) Weekly wages are wages paid by employers to workers or workers depending on the agreement of the two parties.

c. Region coverage applies

1) Provincial minimum wage (UMP)

The Provincial Minimum Wage (UMP) is the minimum wage that applies to all districts or cities in one province.

2) Minimum wage of districts or cities (MSEs) 
District/City Minimum Wage (UMK) is the minimum wage that applies in a region or city.

The most principled thing in the minimum wage policy is as an effort to realize a decent income for workers or workers, taking into account the improvement of the welfare of workers or workers without neglecting the increase in productivity and progress of the company and the development of the economy in general. The legal basis for setting the minimum wage is Regulation of the Minister of Manpower and Transmigration No. 7 of 2013 concerning minimum wage, which is enhanced by the Decree of the Minister of Manpower and Transmigration Number KEP-226/MEN/2000 and Regulation of the Minister of Manpower and Transmigration Number PER17/MEN/VIII/2005.

In Article 1 number 2 of The Minister of Manpower and Transmigration Regulation No. 7 of 2013 concerning the minimum wage explained, that what is meant as UMP is the lowest monthly wage consisting of basic wages including fixed allowances set by the governor as a safety net that applies to all districts or cities in one province. Thus, it can be known that UMP is the lowest monthly wage consisting of basic wages, including fixed benefits.

Article 94 of Law No. 13 of 2003 on Manpower stipulates that the amounts of basic wages is at least $75 \%$ of the total basic wage and fixed benefits are payments to workers made regularly and are not associated with the presence of workers or achievement of certain work performance.

While in wages is also known as overtime wages which is an obligation for employers to pay to workers or workers who have worked beyond the agreed working time provisions. This means that employers are required to pay overtime wages if workers or workers do work beyond the mandatory working time. The definition of overtime time refers to Article 1 KEP-102/MEN/VI/2004, which is as follows:
1) Working time exceeding 7 hours in 1 day and 40 hours in a week for 6 working days in 1 week.

2) Working time 8 hours in 1 day and 40 hours in 1 week for 5 working days in 1 week.

3) Working time on weekly rest days and/or on official governmentdesignated holidays.

The way overtime wages are calculated is as follows:

a) Apabila kerja lembur dilakukan pada hari kerja:

(1). Untuk jam kerja lembur pertama harus dibayar upah sebesar $150 \%$ sejam.

(2). Untuk jam kerja lembur berikut harus dibayar upah sebesar 200\% kali upah sejam.

b) If overtime work is done on a weekly break and/or official holiday working time of 6 working days 40 hours a week, then the calculation:

(1).For the first 7 hours are paid 200\% times the hourly wage, the 8th hour is paid $300 \%$ times the hourly wage, then the 9th and 10th hours are paid $400 \%$ times the hourly wage.

(2). If the official holiday falls on the shortest working day the calculation of the first 5 hours overtime wages is paid $200 \%$ times the hourly wage, the 6th hour is paid $300 \%$ times the hourly wage.

If overtime work is done on weekly breaks and/or official holidays for working time 5 working days and 40 hours a week, then the calculation of overtime wages of the first 8 hours is paid $200 \%$ times the hourly wage, the 9th working hour is paid $300 \%$ times the hourly wage, and the 10th hour is paid $400 \%$ times the hourly wage

\section{Law Enforcement in the Criminal Justice System in the Field of Employment Definition of The Employment Criminal Justice System}

Criminal Justice is a process in which several law enforcement agencies and their officers work. Criminal justice activities are gradual activities starting from 
investigation, prosecution, examination at trial and ended with the implementation of the verdict by the correctional institution. (Tri Andrisman ,2019) This ongoing activity is a series of integrated activities between the police, prosecutors, judges and correctional officers, so that criminal justice is a system.

According to Muladi stated that: (Mulad, 2015) The Criminal Justice System will involve the enforcement of criminal law, both substantive criminal law, formil criminal law and criminal implementation law. Besides that, it can also be seen the form of both preventive, repressive and curative. Thus, there will be interrelationship and interdependence between the criminal justice sub-systems, namely police agencies, prosecutors, courts and correctional institutions. It can even be added here legal advisory institutes and communities.

Integrated Criminal Justice System (ICJS) is a very important element of criminal law in terms of material criminal law enforcement. Philip. P. Purpura states that (Tri Andrisman ,2019) criminal justice system is a system consisting of police, prosecutors, courts, and correctional institutions aimed at protecting and maintaining public order, controlling crimes, making arrests, and detention of criminals, limiting the guilt or innocence of a person, criminalizing guilty offenders and through the components of the system as a whole can provide legal protection against the rights of defendants.

The criminal justice system that we already have as illustrated in kuhap (Law No. 8 of 1981), is an illustration of how the components of criminal law that we have are less able to be expected to control the enforcement of criminal law materil. The fundamental weakness seen from kuhap is the neglect of the rights of suspects / defendants / convicted and victims of crimes that must be considered the possibility of obtaining legal protection for their rights as victims of crime, not getting adequate arrangements. Romli Atmasasmita expressed his opinion on the Criminal Justice System, that the Criminal Justice System is an interconnection between the decisions of each agency involved in the criminal justice process. (Romli Atmasasmita, 2016) It can be concluded based on the theory of proof of the Criminal Justice System adheres to the negative system as stipulated in the Criminal Procedural Law (KUHAP).

\section{Judge's Decision on Employment Crimes}

State law, judicial power (judiciary) is a very decisive body against the substance and strength of positive legal rules including criminal law. It is through this body that positive legal concreteization is carried out by the judge on his decisions before the court. In other words, it can be said that however good all the rules of criminal law created in a country, in the effort to combat crime, but those rules are meaningless if there is no judicial power exercised by judges who have the authority to give content and power to the norms of criminal law. Iskandar Kamil gave an opinion on the duty of the judge as follows: The duty of the judge is as the executor of an independent Judicial Authority to organize the judiciary in order to uphold the law and justice, which is basically to adjudicate. The word adjudicating is a simple formulation, but it contains a very basic, broad and noble understanding, namely reviewing and establishing things fairly or giving justice. The granting of justice must be done freely and independently. In order to realize the functions and duties of the judge, the implementation of the judiciary must be technically professional and non-political and non-partisan. The judiciary is conducted in accordance with professional standards based on the provisions of applicable law, without political considerations and influence of the interests of the parties. (Iskandar Kamil, 2003)

From the description and view above, law enforcement and justice is the basis of the philosophy of the independence of this judge. Given the philosophical basis for 
upholding this law and justice, the judge needs to be given freedom from the influence of judicial ectra power in carrying out the functions and authority of the judiciary. However, freedom must be realized only is the freedom given by law or law (legal right) not natural right. Therefore, the Chief Justice of the Supreme Court in his keynote speech said, that the freedom of the judge is limited to:( Chairman of the Supreme Court of Indonesia, 1995)

a. Free from interference of other state powers.

b. Free from anyone's coercion,

c. Free from assets or recommendations coming from the judicial ectra.

As the philosophical basis of the freedom of judges, justice itself has a meaning so rich, that it always raises differences and contradictions in interpreting it. Nevertheless, it may be attempted a basic and fundamental understanding so that it can be agreed by many parties that justice carries the goal to be achieved from the independence of the judge in conducting the trial.

This sense of justice in the recent period has been widely reviewed from various points of view. Some see in terms of legal justice that is justice in accordance with the law. This view can be seen from the prevailing laws and regulations and from the decision of the court judges that reflect the fairness of the state law in its formal form. However, whether or not a rule of law or judge's decision is very much determined by the representation of moral justice and social justice, as the other two points of view see justice itself.

If the court holds that from the results of the examination at the trial, the defendant's guilt for the acts charged to him is not proven legally and convincingly, then the defendant is freed. (PENAL CODE) If the court holds that the alleged act is proven, but the act does not constitute a criminal offence, then the defendant is dismissed from all lawsuits. (PENAL CODE) In the case as referred to in paragraphs (1) and (2), the defendant in custody is ordered to be released immediately unless for any other valid reason the accused needs to be detained. (PENAL CODE)

The judge in obtaining the conviction of various circumstances that the judge knows from outside the court must obtain from the tools of valid evidence contained in the trial, in accordance with the conditions specified in the Law.

In addition, the judge's decision is also guided by 3 (three) things, namely: ( Kapita selekta Criminal Corruption, 2003)

a) Juridical elements that are the first and foremost elements

b) Philosophical elements of truth and justice

c) The sociological element is to consider the cultural values that live and develop in society.

District court rulings can be appealed and cassation. As soon as the verdict of the criminal is pronounced, that the presiding judge of the court shall inform the accused of all what is his right, namely (Criminal Code)

a) the right to receive immediately or. immediately reject the verdict;

b) the right to study the award before expressly accepting or rejecting the award, within the period specified by this law;

c) the right to request to suspend the implementation of the award within the period specified by the law in order to apply for clemency, in the event that he accepts the award;

d) the right to have the case examined at the appeal level within the time limit specified by this law, in the event that He rejects the award;

e) the right to revoke the statement as referred to in letter a within the period specified by this law.

\section{Sanctions Against Wage Violations}

Violations committed by workers or workers due to gaps or negligence of gaps or negligence result in late payment of wages, due to fines in accordance with a 
certain percentage of the wages of workers or workers. The imposition of fines on employers and/or workers or workers, in the payment of wages is regulated by the government. In the event that the company is declared bankrupt under the prevailing laws and regulations, the wages and other rights of the worker or laborer shall be the debt that precedes the payment.

While the criminal sanctions in violation of this wage based on the provisions of Article 23 PP No. 36 of 2021 Juncto Article 90 paragraph 1 UUK, it is stated that employers are prohibited from paying wages lower than the minimum wage as referred to in Article 89, if the employer violates the provisions of Article 90 paragraph (1), according to the provisions of Article 185 paragraph (2) Employers are classified as having committed criminal offences. Furthermore, employers may be subject to criminal sanctions as stipulated in Article 185 paragraph (1) of Law No. 13 of 2003 on Employment which reads: "Anyone who violates the provisions as referred to in Article 42 paragraph (1) and paragraph (2), Article 68, Article 69 paragraph (2), Article 80, Article 82, Article 90 paragraph (1), Article 143 and Article 160 paragraph (4) and paragraph (7), shall be subject to imprisonment for a minimum of 1 (sat) year and a maximum of 4 (four) years and/or a fine of at least Rp.100,000,000 (one hundred million rupiah) and a maximum of Rp.400,000,000 (four hundred million rupiahs)".

The provisions of Article 185 paragraph (1) have been applied in a criminal case in the Surabaya District Court which continues until the cassation to the Supreme Court with Cassation Case Number No. 867 K/Pid.Sus/2012 where the cassation judge in his ruling punishes the Entrepreneur with a minimum penalty of 1 (one) year and a fine of Rp.100,000,000 (one hundred million rupiah). The Supreme Court sentenced Tjio Chrstina Chandra, a Surabaya-based businessman, to pay his employees below the regional minimum wage. The criminal sanction on the businessman was the first in Indonesia. The cassation verdict was led by the chairman of the Panel of Judges Zaharuddin Utama, with assembly members Prof Dr Surya Jaya and Prof Dr Gayus Lumbun in the case No. 687 K/Pid.Sus/2012.

The judge in sentencing the criminal should also consider the sense of justice for the accused and the community, because the purpose of criminalization is not merely retaliation but as a preventive and repressive so that the defendant can reflect on the next act and the punishment imposed not also to lower the human level, but is educational, motiveative so that the defendant does not do the act again in the future and preventive for other communities so that therefore the defendant must be sentenced as in the amar verdict.

\section{CONCLUSION}

Criminal Law Policy Against Criminal Acts in the Field of Manpower is the regulation of criminal matters in relation to employment issues in the national legislation aimed at maintaining synchronization of employment relations between employers and workers and putting the function of government as a function of harmonization between employers and workers. The purpose of normative regulation regarding employment relations is to maintain orderly working relationships between workers and employers. In order to maintain order, it is necessary to behave in the form of normative law (legal certainty), and directed at the legal mind, namely justice and benefit. Employment law in the legal constitution (Indonesia) is the implementation of basic philosophy, namely Pancasila and basic theory (UUD. 1945). The basic values have aspects of legal certainty, justice, benefit. This certainty at the same time reflects the value of justice, which provides benefits for the survival of workers and employers in the company corridor, as well as in terms of criminal law enforcement in the field of employment can provide a benefit to the fulfillment of the 
provisions of legislation on employment, especially in articles related to criminal provisions.

\section{Acknowledgement: None}

\section{Conflict of Interest: None}

\section{Source of Funding: None}

\section{REFERENCES}

1. Asyhadi, Zaini, 2017, Employment Law, PT. Raja Grafindo Persada, Jakarta.

2. Azhary. 2015, State Law of Indonesia, UIPress, Jakarta

3. Andrisman, Tri, Corruption Law Enforcement Analysis by the Corruption Eradication Commission (KPK), httpdownload.portalgaruda.orgarticle.phpart icle $=250498 \& \mathrm{va}$

$\mathrm{l}=6697 \&$ title $=$ Analisis $\% 20$ Penegakan $\% 20 \mathrm{H}$ ukum\%20Tindak\%20Pidana\%20Korupsi\%2 0Oleh\%20Komisi\%20Pemberantasan\%20K orupsi\%20(KPK), diakses tanggal 12 Desember 2019.

4. Atmasasmita, Romli, 2016, Criminal Justice System, Putra Bardin, Jakarta.

5. Budiono, Abdul R, 2015, Labor Law, PT. Indeks, Jakarta.

6. Hamzah, Andi, 2007, KUHP dan KUHAP, Rineka Cipta, Jakarta.

7. Hutagalung, TH, 1995, Law and Justice in The Philosophical Thinking of Pancasila and the 1945 Constitution, Disertasi, Fakultas Hukum Universitas Pajajaran, Bandung.

8. Kamil, Iskandar , 2003, Code of Professional Ethics of Judges, in the Code of Conduct of Judges (Code of Conduct) Code of Ethics of Judges and Related Papers, Mahkamah Agung RI, Jakarta

9. Ketua Mahakamah Agung RI, Judge As Legal Mandate Holder Implements, Interprets and Enforces The Establishment of The Law, 1995, keynote speech at a panel discussion on The Freedom of Judges in the State of Indonesia Based on The Law, Directorate General of The General Justice and Administrative Justice Of the Ministry of Justice.

10. Kapita selekta Corruption Crimes, 2003, Pusdiklat MARI.

11. Muhtoj, Majda El, 2015, Human Rights in the Indonesian Constitution, Prenada Media, Jakarta.

12. Muladi, Kapita Selekta Criminal Justice System, 2015, Badan Penerbit Universitas Diponegoro, Semarang.

13. Mukthi, Fadjar A, 2014 Types of Legal States, Bayumedia Publishing, Malang.

14. M. Peter Mahmud, 2005, Legal Research, Kencana Prenada Media Group, Jakarta.

15. Prasetyo, Teguh, 2010, Criminalization In Criminal Law, Nusa Media, Bandung.

16. Pujirahayu, EW, 2011 Community Empowerment in Realizing Legal Objectives, FH. Universitas Diponegoro, Semarang.

17. Wage And Severance Legislation, 2006, Indonesia Legal Center Publishing, Jakarta.

18. Santoso, Budi, 2012Chapters on Labor Law, Pustaka Larasan, Bali.

19. Shant, Dellyana, 2008, Law Enforcement Concept, Liberty, Yogyakarta.

20. Soepomo, Iman, 2018, Introduction to Labor Law, Djambatan, Jakarta.

21. Soekanto, Soerjono, 2008, Criminology: An Introduction, Ghalia Indonesia, Jakarta.

22. S, Djoko Heroe, 2006, Existence of Employment Law in Creating Partnership Relationships Between Workers and Employers, Disertasi, Pascasarjana, Fakultas Hukum Universitas Brawijaya.

23. Undang-undang Nomor 8 Tahun 1981 tentang Criminal Procedural Law (KUHAP)

24. www.wartaekonomi.co.id/read134562/keme naker-pengusaha-bisa-dibui-bila-bayar-gajidi-bawah-upah-minimum.html, Access on June, $28^{\text {th }} 2021$

How to cite this article: Nurhayati S, Sumarno. Law enforcement against the implementation of the provisions payment of workers' wages is reviewed from aspects of employment criminal law. International Journal of Research and Review. 2021; 8(9): 57-71. DOI: https://doi.org/ 10.52403/ijrr.20210910 